\title{
PENGOLAHAN BAKTO AGAR DARI RUMPUT LAUT MERAH (Rhodymenia ciliata) DENGAN PRA PERLAKUAN ALKALI
}

\begin{abstract}
Muhamad Darmawan ${ }^{\star}$, Syamdidi*) dan Ema Hastarini*)
ABSTRAK

Penelitian pengolahan bakto agar dari rumput laut merah (Rhodymenia ciliata) dengan pra perlakuan alkali telah dilakukan untuk melihat pengaruh konsentrasi $\mathrm{NaOH}$ dan waktu pra perlakuan alkali terhadap mutu bakto agar yang dihasilkan. Konsentrasi $\mathrm{NaOH}$ yang ditambahkan adalah 5, 6 dan 7\% dan waktu pra perlakuan alkali yang digunakan adalah 30, 45 dan 60 menit. Parameter yang diamati meliputi rendemen, kadar air, kadar abu, kadar sulfat dan kekuatan gel. Hasil penelitian menunjukkan bahwa variasi konsentrasi $\mathrm{NaOH}$ dan waktu pra perlakuan alkali memberikan pengaruh nyata terhadap rendemen, kadar sulfat dan kekuatan gel bakto agar, tetapi tidak memberikan pengaruh nyata terhadap kadar air dan abu. Hasil terbaik diperoleh dari perlakuan konsentrasi $\mathrm{NaOH} 7 \%$ dan waktu pra perlakuan 60 menit dengan rendemen $14,32 \%$, kadar air $13,12 \%$, kadar abu $4,99 \%$, kadar sulfat $1,90 \%$ dan kekuatan gel $748,5 \mathrm{~g} / \mathrm{cm}^{2}$.
\end{abstract}

\begin{abstract}
Processing of bacto agar from red seaweed (Rhodymenia ciliata) by alkali pre-treatment. By: Muhamad Darmawan, Syamdidi and Ema Hastarini

Experiment on processing of bacto agar from red seaweed (Rhodymenia ciliata) by alkali pre-treatment had been conducted, to reveal the effect of $\mathrm{NaOH}$ concentration and pre-treatment time on the quality of bacto agar produced. The $\mathrm{NaOH}$ concentrations of 5,6 , and $7 \%$ and pretreatment time of 30, 45, and 60 minutes were used in this experiment respectively. Parameters observed were yield, moisture, ash and sulphate content as well as the gel strength of bacto agar. Results indicated that alkali concentration and its pre-treatment time gave significant effects on yield, sulphate content as well as the gel strength of bacto agar. However, such treatments gave insignificant effects on the moisture and ash contents. The best quality of bacto agar was obtained by using $7 \% \mathrm{NaOH}$ combined with 60 minutes alkali pre-treatment, giving $748.5 \mathrm{~g} / \mathrm{cm}^{2} \mathrm{gel}$ strength, $1.90 \%$ sulphate content, $13.12 \%$ moisture content, $4.99 \%$ ash content, while the yield of bacto agar was $14.32 \%$.
\end{abstract}

KEYWORDS: $\quad$ bacto agar, $\mathrm{NaOH}$ concentration, alkali pre-treatment time, Rhodymenia ciliata

\section{PENDAHULUAN}

Rumput laut merah merupakan salah satu jenis rumput laut yang memiliki nilai ekonomis penting karena menghasilkan agar-agar. Beberapa jenis rumput laut merah yang dapat dimanfaatkan sebagai bahan pembuatan agar-agar adalah Gracilaria, Gelidium, Gigartina, dan Rhodymenia. Jenis yang paling banyak dikembangkan di Indonesia adalah jenis Gracilaria karena selain dapat diperoleh dari alam juga telah dibudidayakan, sedangkan untuk jenis Rhodymenia masih diperoleh dari alam. Rumput laut jenis Rhodymenia memiliki keunggulan dibandingkan dengan jenis Gracilaria. Kekuatan gel agar-agar yang dihasilkan dari rumput laut jenis Rhodymenia lebih baik bila dibandingkan dengan hasil dari jenis Gracilaria. Kekuatan gel agar-agar yang diproduksi dari rumput laut jenis Gracilaria sp. sebesar $30 \mathrm{~g} / \mathrm{cm}^{2}$
(Utomo et al., 2003), sedangkan kekuatan gel agaragar yang diproduksi dari rumput laut jenis Rhodymenia ciliata sebesar $56,83 \mathrm{~g} / \mathrm{cm}^{2}$ (Chasanah, 2004). Pengolah agar-agar biasanya mencampur rumput laut jenis Gracilaria dengan jenis Rhodymenia dalam proses pembuatan agar-agar dengan komposisi tertentu yang bertujuan untuk mendapatkan kualitas agar-agar yang lebih baik bila dibandingkan dengan hanya menggunakan bahan baku dari jenis Gracilaria.

Di Indonesia agar-agar dikenal dalam bentuk lembaran, batangan maupun tepung. Pengolahan rumput laut merah menjadi agar-agar semula hanya dimanfaatkan sebagai bahan makanan ataupun obatobatan. Dengan adanya kemajuan teknologi serta perbaikan dari segi teknik pengolahannya maka agaragar dapat ditingkatkan nilainya menjadi suatu produk yang bernilai ekonomis tinggi. Salah satu bentuk

Peneliti pada Balai Besar Riset Pengolahan Produk dan Bioteknologi Kelautan dan Perikanan 
produk agar yang memiliki nilai ekonomis tinggi adalah bakto agar yang banyak digunakan dalam bidang farmasi yaitu sebagai media kultur mikroorganisme.

Bakto agar merupakan agar-agar yang telah dimurnikan dengan mereduksi kandungan pigmenpigmen pengotor dan kandungan bahan-bahan asing (organik dan inorganik) serendah mungkin sehingga dapat mendukung pertumbuhan mikroba secara umum (Gelrited, 2003 dalam Abdullah, 2004). Pemanfaatan sebagai media kultur mikroorganisme ini belum berubah sejak Dr. Robert Koch memakai pertama kalinya tahun 1982 untuk kultur media bakteri tuberkulosa. Dengan kemajuan teknik rekombinasi DNA dan fusi sel, maka kegiatan seleksi, kloning dan propagasi mikroorganisme yang direkayasa juga dilakukan dalam media agar (Rasyid et al., 1998).

Bakto agar biasa digunakan untuk media kultur bakteri patogen maupun bakteri non-patogen. Sebanyak $1 / 6$ dari total produksi agar-agar yang ada di Amerika Serikat digunakan untuk keperluan mikrobiologi sebagai media kultur bakteri (Anon., 2004a). Permintaan pasar internasional untuk agaragar yang digunakan sebagai media kultur bakteri terus meningkat (Winarno, 1990). Pemanfaatan bakto agar untuk bidang mikrobiologi di dalam negeri juga semakin meningkat. Namun produksi bakto agar belum mencukupi kebutuhan di dalam negeri. Salah satu solusi adalah dengan membuat bakto agar produksi dalam negeri dengan karakteristik mutu yang diharapkan sama dengan bakto agar impor.

Bakto agar yang digunakan sebagai kultur media memiliki beberapa karakteristik yaitu memiliki kekuatan gel, tingkat elastisitas, kejernihan dan stabilitas yang baik (Anon., 2004a). Food grade agar memiliki kisaran kekuatan gel antara $150-250 \mathrm{~g} / \mathrm{cm}^{2}$, sedangkan bakto agar memiliki kisaran kekuatan gel berkisar antara $400-500 \mathrm{~g} / \mathrm{cm}^{2}$ untuk reguler grade, $500-650 \mathrm{~g} / \mathrm{cm}^{2}$ untuk standard grade dan di atas 650 $\mathrm{g} / \mathrm{cm}^{2}$ untuk premium grade (Anon., 2004b). Peningkatan kekuatan gel dari agar yang dihasilkan dapat dilakukan dengan menambah tahapan ekstraksi yaitu melakukan pra perlakuan alkali. Perlakuan alkali yang diberikan pada pembuatan agar tergantung dari kualitas rumput laut yang digunakan sebagai bahan baku (Anon., 2004a). Hasil penelitian Chasanah (2004) menunjukkan bahwa peningkatan konsentrasi $\mathrm{NaOH}$ dari 0 hingga $4 \%$ dalam proses pra perlakuan alkali dengan suhu $70^{\circ} \mathrm{C}$ selama 90 menit mampu meningkatkan kekuatan gel agar-agar yang diproduksi dari rumput laut jenis Rhodymenia ciliata dari 56,83 $\mathrm{g} / \mathrm{cm}^{2}$ menjadi $198,57 \mathrm{~g} / \mathrm{cm}^{2}$. Namun demikian kekuatan gel ini belum memenuhi spesifikasi bakto agar komersial sebesar $400-500 \mathrm{~g} / \mathrm{cm}^{2}$ untuk kualitas reguler. Diperkirakan peningkatan konsentrasi $\mathrm{NaOH}$ yang lebih tinggi dapat meningkatkan pula kekuatan gel. Untuk menghindari banyaknya agar-agar yang terekstrak selama pra perlakuan, maka harus diikuti dengan penurunan suhu dan pengurangan waktu. Untuk rumput laut jenis Gracilaria, pra perlakuan alkali umumnya dilakukan menggunakan larutan $\mathrm{NaOH}$ dengan konsentrasi 6-7\% selama 30-120 menit pada suhu $70-90^{\circ} \mathrm{C}$ (Anon., 2004a).

Tujuan dari penelitian ini adalah mempelajari pengaruh konsentrasi dan waktu pra perlakuan alkali untuk menghasilkan bakto agar dengan kualitas standar dari bahan baku rumput laut merah jenis Rhodymenia ciliata.

\section{BAHAN DAN METODE}

\section{Bahan}

Bahan baku yang digunakan dalam penelitian ini adalah rumput laut merah jenis Rhodymenia ciliata. yang dipanen dari perairan Wonosari, Kabupaten Gunung Kidul, Daerah Istimewa Yogyakarta.

Bahan kimia yang dipakai antara lain larutan $\mathrm{CaO}$, sodium hidroksida $(\mathrm{NaOH})$ dan poly ethylene glycol (PEG) 6000.

\section{Metode}

Rumput laut merah dicuci dengan air tawar untuk menghilangkan kotoran-kotoran yang masih melekat pada rumput laut seperti lumpur dan garam. Selanjutnya, rumput laut dikeringkan di bawah panas matahari. Penjemuran dilakukan di atas para-para atau di atas tanah yang diberi alas untuk menghindari pencemaran dari benda asing hingga rumput laut tersebut kering. Rumput laut merah yang telah kering dikemas dalam karung-karung plastik bersih kemudian dibawa ke Laboratorium Pengolahan, Balai Besar Riset Pengolahan Produk dan Bioteknologi Kelautan dan Perikanan, Jakarta.

Selanjutnya rumput laut merah kering tersebut direndam dan dicuci dengan menggunakan air bersih, kemudian dipucatkan dengan larutan $\mathrm{CaO} 1 \%$ selama $1 \mathrm{jam}$. Setelah itu rumput laut dicuci kembali hingga $\mathrm{pH}$ netral dan kemudian dilanjutkan dengan tahapan pra perlakuan alkali. Pada proses pra perlakuan alkali, rumput laut dimasukkan ke dalam larutan $\mathrm{NaOH}$ dengan perbandingan 1:10. Konsentrasi larutan $\mathrm{NaOH}$ yang digunakan berbeda-beda sesuai dengan perlakuan yang akan digunakan $(5 \%, 6 \%$ dan $7 \%)$. Selama pra perlakuan ini rumput laut dipanaskan pada suhu $50-60^{\circ} \mathrm{C}$ dengan waktu pemanasan bervariasi menurut perlakuan yaitu 30,45 dan 60 menit.

Setelah proses pra perlakuan alkali selesai, rumput laut dicuci kembali dengan menggunakan air bersih hingga $\mathrm{pH}$ netral. Proses selanjutnya adalah 


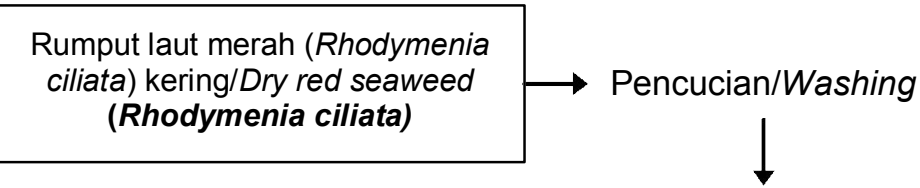

Pemucatan dengan larutan $\mathrm{CaO} 1 \%$ selama 1 jam/ Bleaching with $1 \% \mathrm{CaO}$ solution for 1 hour

Pencucian sampai $\mathrm{pH}$ netral/Washing until neutral $\mathrm{pH}$

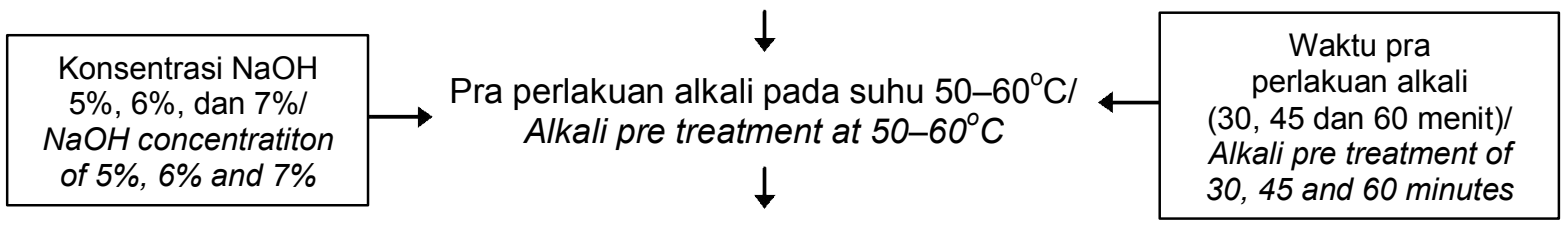

Pencucian/Washing

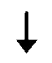

Ekstraksi pada suhu $80-90^{\circ} \mathrm{C}$ selama 2 jam (air : rumput laut $=20: 1$ )/

Extraction at $80-90^{\circ} \mathrm{C}$ for 2 hours (water : seaweed $=20: 1$ )

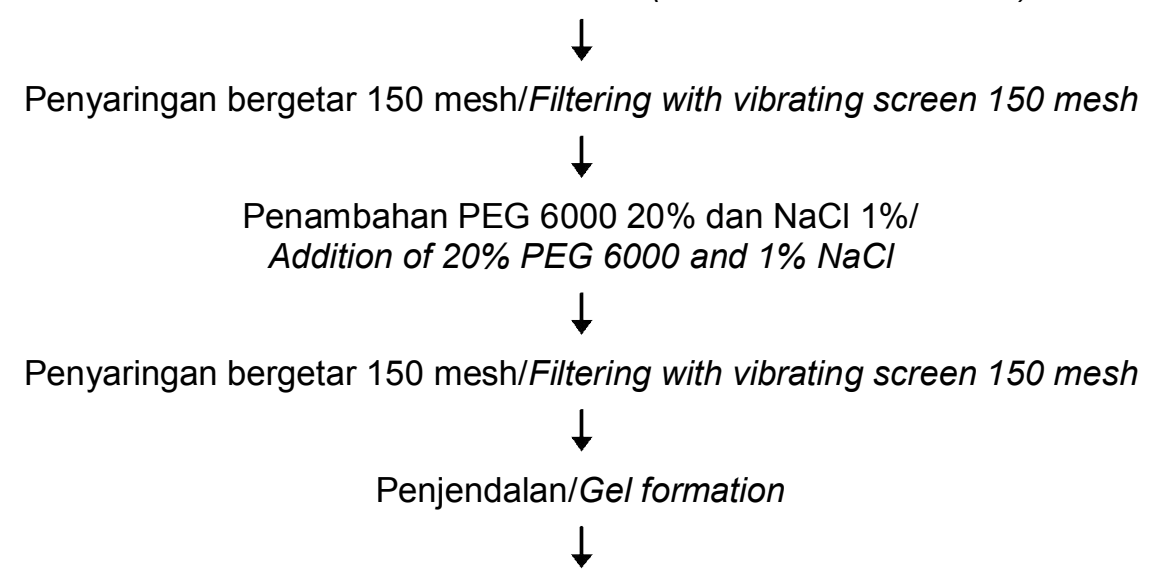

Pemotongan menjadi lembaran $1 \mathrm{~cm} /$ Cutting into $1 \mathrm{~cm}$ sheets

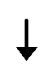

Pembungkusan dengan kain/Wrapping with cotton fabric

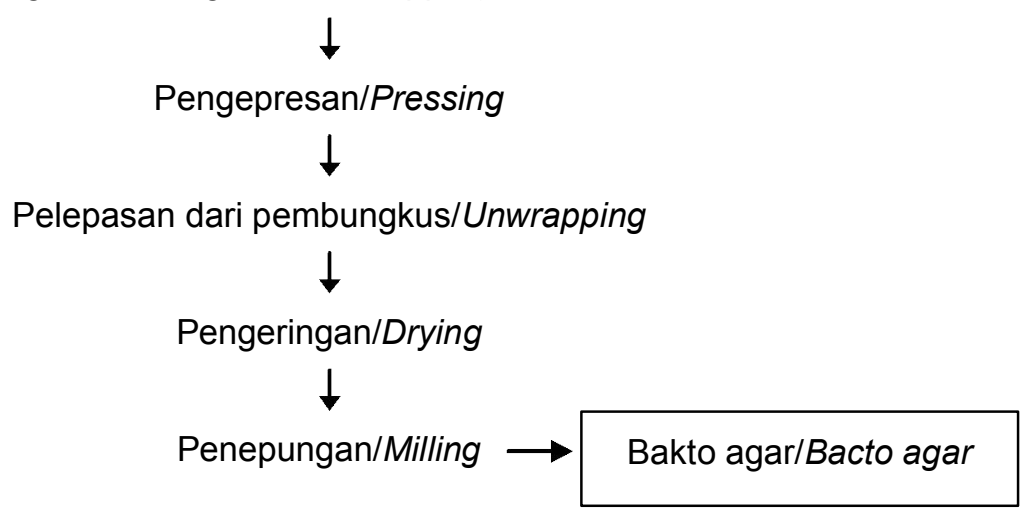

Gambar 1. Diagram pembuatan bakto agar dari rumput laut merah (Rhodymenia ciliata).

Figure 1. Flow chart of bacto agar production from red seaweed (Rhodymenia ciliata). 
melakukan ekstraksi terhadap rumput laut. Pada tahapan ini rumput laut dimasukkan ke dalam air dengan perbandingan 1:20 dan dipanaskan pada suhu $80-90^{\circ} \mathrm{C}$ selama 2 jam. Rumput laut yang telah diekstraksi kemudian disaring dengan menggunakan saringan bergetar (vibrating screen) yang memiliki ukuran 150 mesh. Ke dalam filtrat hasil penyaringan ditambahkan PEG 6000 sebanyak $20 \%$ (b/v) dan $\mathrm{NaCl}$ sebanyak $1 \%$ (b/v) lalu dipanaskan kembali selama 30 menit. Setelah proses pemanasan selesai filtrat disaring kembali dengan menggunakan vibrating screen ukuran 150 mesh. Filtrat kemudian dijendalkan dengan cara dimasukkan ke dalam pan-pan pencetakan dengan ukuran $29 \times 19 \times 10 \mathrm{~cm}$ dan didiamkan selama 24 jam pada suhu kamar.

Filtrat yang telah menjendal kemudian dipotong horisontal dengan ketebalan $1 \mathrm{~cm}$ lalu masing-masing potongan dibungkus dengan menggunakan kain blacu. Bakto agar yang telah dibungkus kain kemudian disusun dalam alat pengepres sampai ketinggian 50 $\mathrm{cm}$. Tumpukan tersebut dipres selama 24 jam dengan cara memberi beban (batu) di bagian atasnya. Hasil pengepresan yang berupa lembaran bakto agar tipis dijemur selama 1-2 hari hingga kering. Bakto agar yang telah kering kemudian dilepaskan dari kain pembungkusnya dan dihancurkan dengan menggunakan mesin penghancur (grinding mill) sehingga didapatkan bakto agar dengan ukuran 100 mesh.

Penelitian ini menggunakan rancangan acak lengkap dengan dua perlakuan yaitu konsentrasi $\mathrm{NaOH}$ dan waktu pra perlakuan alkali. Taraf konsentrasi $\mathrm{NaOH}$ yang digunakan adalah $5 \%, 6 \%$ dan $7 \%$. Sedangkan waktu pra perlakuan alkali yang digunakan adalah 30, 45 dan 60 menit.

Analisis yang dilakukan terhadap bakto agar yang dihasilkan meliputi rendemen, nilai kekuatan gel (gel strength) dengan menggunakan alat Texture Analyzer, kadar sulfat (Anon., 1991) serta kadar air dan kadar abu (AOAC, 1984). Data yang diperoleh dianalisis secara statistik dan dilakukan uji lanjut beda nyata jujur (Steel \& Torrie, 1993).

\section{HASIL}

\section{Rendemen}

Rendemen bakto agar yang dihasilkan berkisar antara $14,32 \pm 2,81 \%$ sampai dengan $25,45 \pm 1,21 \%$. Nilai rata-rata rendemen bakto agar yang dihasilkan dapat dilihat pada Gambar 2.

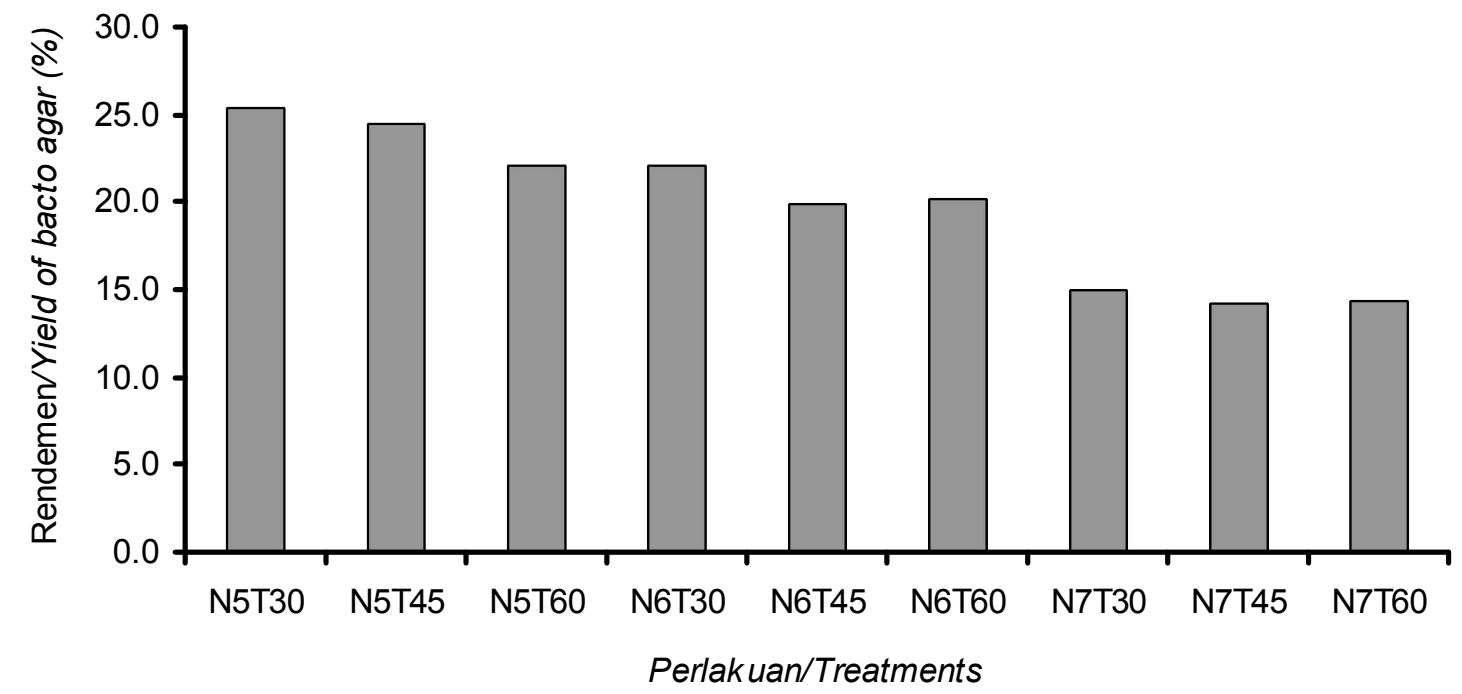

\footnotetext{
Keterangan/Note : $\quad \mathrm{N} 5=\mathrm{NaOH} 5 \%$

$\mathrm{N} 6=\mathrm{NaOH} 6 \%$

$\mathrm{N} 7=\mathrm{NaOH} 7 \%$

$\mathrm{T} 30=$ pra perlakuan alkali 30 menit $/ 30$ minutes alkali pre-treatment

$\mathrm{T} 45$ = pra perlakuan alkali 45 menit $/ 45$ minutes alkali pre-treatment

T60 = pra perlakuan alkali 60 menit $/ 60$ minutes alkali pre-treatment
}

Gambar 2. Pengaruh konsentrasi $\mathrm{NaOH}$ dan waktu pra perlakuan alkali terhadap rendemen bakto agar.

Figure 2. Effect of $\mathrm{NaOH}$ concentration and alkali pre-treatment on the yield of bacto agar. 
Perlakuan variasi konsentrasi $\mathrm{NaOH}$ memberikan pengaruh yang nyata terhadap rendemen bakto agar yang dihasilkan. Perlakuan variasi waktu pra perlakuan alkali dan interaksi antar dua perlakuan tersebut tidak menunjukkan pengaruh yang nyata terhadap rendemen bakto agar. Hasil uji lanjut beda nyata jujur terhadap perlakuan variasi konsentrasi $\mathrm{NaOH}$ diketahui bahwa konsentrasi $\mathrm{NaOH} 7 \%$ memberikan pengaruh yang nyata terhadap rendemen bakto agar, sedangkan perlakuan 5 dan $6 \%$ tidak menunjukkan pengaruh yang nyata terhadap rendemen bakto agar.

Dari Gambar 2 diketahui bahwa peningkatan konsentrasi $\mathrm{NaOH}$ menyebabkan terjadinya penurunan rendemen bakto agar yang dihasilkan. Hal ini terjadi karena pada saat proses pra perlakuan alkali berlangsung sebagian komponen agar yang ada dalam rumput laut ikut terekstrak dan ikut terbuang pada saat pencucian setelah proses pra perlakuan alkali selesai (Anon., 2004a). Hasil penelitian Amnidar (1989) juga menunjukkan terjadinya penurunan rendemen agar-agar yang dihasilkan seiring dengan peningkatan konsentrasi $\mathrm{NaOH}$ yang digunakan dalam proses pembuatan agar-agar.

\section{Kadar Air}

Nilai rata-rata kadar air yang dihasilkan pada penelitian ini adalah berkisar antara 12,32 $\pm 0,10 \%$ sampai dengan $15,33 \pm 0,18 \%$. Kadar air bakto agar yang dihasilkan dapat dilihat pada Gambar 3. Perlakuan variasi konsentrasi $\mathrm{NaOH}$, variasi waktu pra perlakuan alkali dan interaksi antar kedua perlakuan tidak memberikan pengaruh yang nyata terhadap kadar air bakto agar yang dihasilkan. Hal ini karena proses pengurangan jumlah air dan pengeringan terhadap agar yang dihasilkan untuk semua perlakuan adalah sama yaitu proses pengepresan dan proses pengeringan di bawah sinar matahari.

Bila dibandingkan dengan bakto agar komersial maka kadar air bakto agar dari Rhodymenia ciliata dengan perlakuan perbedaan konsentrasi $\mathrm{NaOH}$ dan waktu pra perlakuan alkali sudah memenuhi spesifikasi bakto agar komersial untuk reguler grade (Tabel 1). Kadar air bakto agar dapat dikurangi dengan cara memperbaiki teknik ekstraksi terutama pada saat proses pengeringan agar yang telah dihasilkan. Pengeringan dengan menggunakan oven dapat

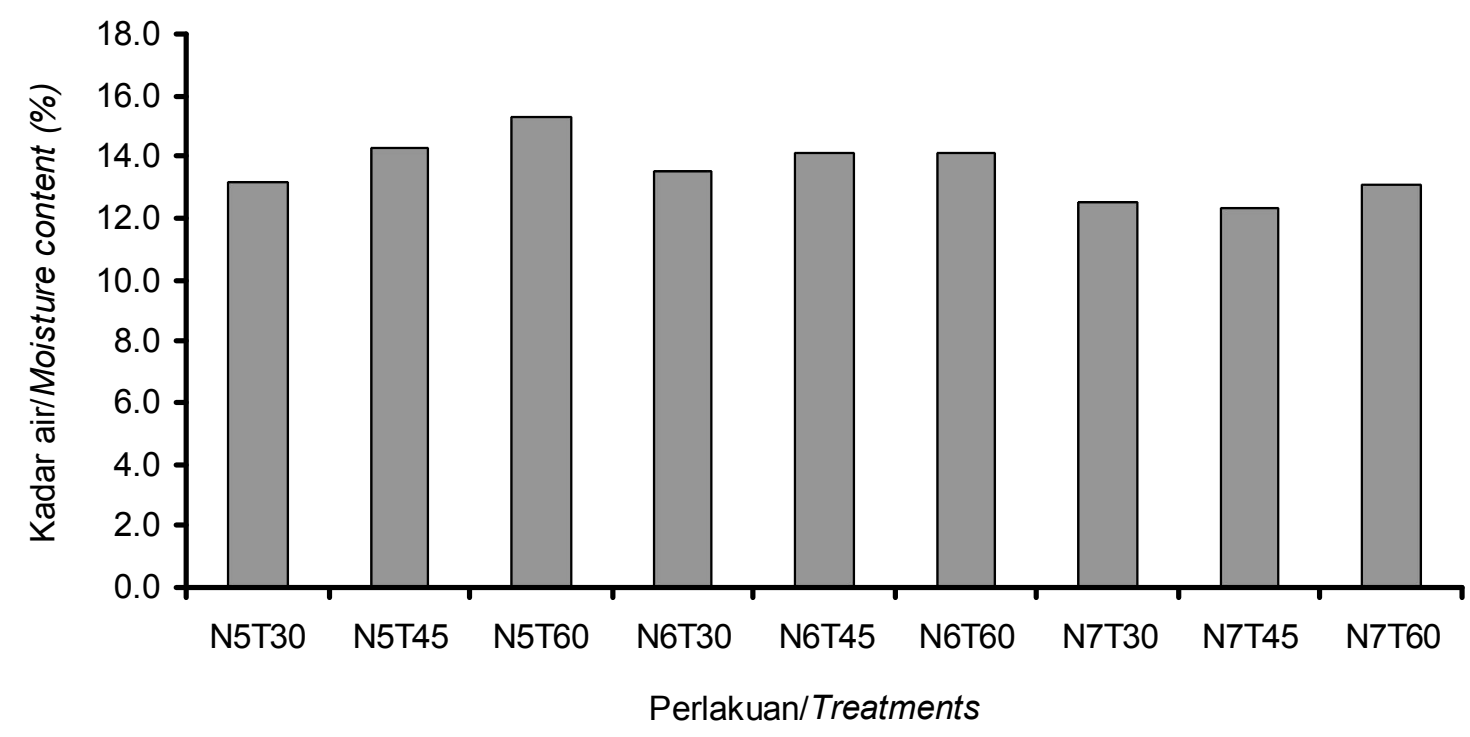

$\begin{array}{ll}\text { Keterangan/Note : } & \mathrm{N} 5=\mathrm{NaOH} 5 \% \\ \mathrm{~N} 6=\mathrm{NaOH} 6 \% \\ \mathrm{~N} 7=\mathrm{NaOH} 7 \% \\ \mathrm{~T} 30=\text { pra perlakuan alkali } 30 \text { menit/30 minutes alkali pre-treatment } \\ \mathrm{T} 45=\text { pra perlakuan alkali } 45 \text { menit/45 minutes alkali pre-treatment } \\ \mathrm{T} 60=\text { pra perlakuan alkali } 60 \text { menit/60 minutes alkali pre-treatment }\end{array}$

Gambar 3. Pengaruh konsentrasi $\mathrm{NaOH}$ dan waktu pra perlakuan alkali terhadap kadar air bakto agar. Figure 3. Effect of $\mathrm{NaOH}$ concentration and alkali pre-treatment on the moisture content of bacto agar. 
menghasilkan kadar air yang lebih kecil sehingga bakto agar yang dihasilkan dapat memenuhi kriteria yang lebih baik (standard dan premium grade). Proses pengeringan dengan menggunakan oven pada suhu $50-55^{\circ} \mathrm{C}$ selama 24 jam pada pembuatan agarosa mampu menghasilkan kadar air dengan kisaran 10,3511,33 \% (Subaryono et al., 2003). Spesifikasi bakto agar komersial dapat dilihat pada Tabel 1.

\section{Kadar Abu}

Kadar abu yang terkandung pada suatu produk menunjukkan tingkat kemurnian produk tersebut.
Tingkat kemurnian sangat dipengaruhi oleh komposisi dan kandungan mineralnya. Kadar abu bakto agar dari Rhodymenia ciliata berkisar antara 3,83 $\pm 0,11 \%$ sampai dengan 5,10 \pm ,12\%. Kadar abu bakto agar yang dihasilkan dapat dilihat pada Gambar 4. Perlakuan variasi konsentrasi $\mathrm{NaOH}$, variasi waktu pra perlakuan alkali dan interaksi antar kedua perlakuan tidak memberikan pengaruh yang nyata terhadap kadar abu bakto agar yang dihasilkan.

Kadar abu bakto agar yang dihasilkan tidak memenuhi persyaratan bakto agar komersial, kecuali untuk perlakuan konsentrasi $\mathrm{NaOH} 5 \%$, waktu pra

Tabel 1. Spesifikasi bakto agar komersial (Supreme Marine Chemical)

Table 1. Commercial bacto agar specifications (Supreme Marine Chemical)

\begin{tabular}{lccc}
\hline \multicolumn{1}{c}{ Parameter/Parameter } & $\begin{array}{c}\text { Regulerl } \\
\text { Regular }\end{array}$ & $\begin{array}{c}\text { Standarl } \\
\text { Standard }\end{array}$ & $\begin{array}{c}\text { Premium/ } \\
\text { Premium }\end{array}$ \\
\hline Kadar air/Moisture content (maks/max) & $15 \%$ & $12 \%$ & $9 \%$ \\
Kadar abu/Ash content (maks/max) & $4.50 \%$ & $4 \%$ & $1 \%$ \\
Kekuatan gel/Gel strength $\left(\mathrm{g} / \mathrm{cm}^{2}\right)$ & $400-500$ & $500-650$ & $>650$ \\
\hline
\end{tabular}

Sumber/Sources: Anon. (2004b).

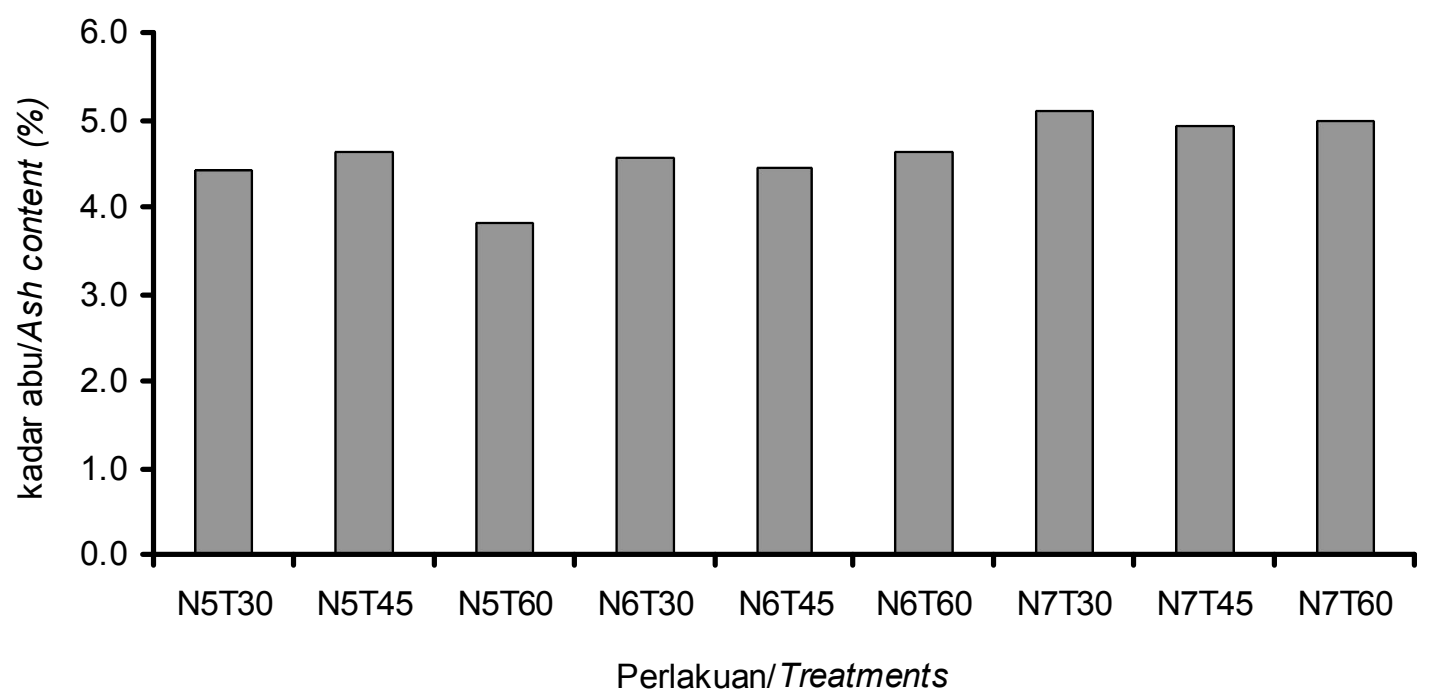

$\begin{array}{ll}\text { Keterangan/Note : } \quad & \mathrm{N} 5=\mathrm{NaOH} 5 \% \\ \mathrm{~N} 6=\mathrm{NaOH} 6 \% \\ \mathrm{~N} 7=\mathrm{NaOH} 7 \% \\ \mathrm{~T} 30=\text { pra perlakuan alkali } 30 \text { menit } / 30 \text { minutes alkali pre-treatment } \\ \mathrm{T} 45=\text { pra perlakuan alkali } 45 \text { menit } / 45 \text { minutes alkali pre-treatment } \\ \mathrm{T} 60=\text { pra perlakuan alkali } 60 \text { menit } / 60 \text { minutes alkali pre-treatment }\end{array}$

Gambar 4. Pengaruh konsentrasi $\mathrm{NaOH}$ dan waktu pra perlakuan alkali terhadap kadar abu bakto agar.

Figure 4. Effect of $\mathrm{NaOH}$ concentration and alkali pre-treatment on the ash content of bacto agar. 
perlakuan alkali 30 menit dan konsentrasi $\mathrm{NaOH} 5 \%$, waktu pra perlakuan alkali 60 menit. Spesifikasi kadar abu bakto agar komersial adalah maksimum 4,5\%. Tingginya kadar abu dari bakto agar yang dihasilkan dapat berasal dari kandungan mineral bahan tersebut dan bahan tambahan yang dipergunakan dalam proses pembuatan bakto agar seperti $\mathrm{NaOH}$ dan bahan lainnya.

\section{Kadar Sulfat}

Kadar sulfat bakto agar yang dihasilkan pada penelitian ini berkisar antara 1,90 $\pm 0,06 \%$ sampai dengan $2,76 \pm 0,06 \%$. Kadar sulfat bakto agar yang dihasilkan dapat dilihat pada Gambar 5 .

Perlakuan variasi konsentrasi $\mathrm{NaOH}$ dan variasi waktu pra perlakuan alkali memberikan pengaruh yang nyata terhadap kadar sulfat bakto agar. Akan tetapi interaksi antara kedua perlakuan tidak memberikan pengaruh yang nyata terhadap bakto agar yang dihasilkan. Hasil uji lanjut BNJ terhadap perlakuan variasi konsentrasi $\mathrm{NaOH}$ diketahui bahwa konsentrasi $7 \%$ memberikan pengaruh yang nyata terhadap bakto agar yang dihasilkan, tetapi konsentrasi $\mathrm{NaOH} 5 \%$ dan $6 \%$ tidak memberikan pengaruh yang nyata terhadap bakto agar yang dihasilkan. Sedangkan uji lanjut BNJ terhadap perlakuan variasi waktu pra perlakuan alkali diketahui bahwa semua perlakuan waktu yang diberikan memberikan pengaruh yang nyata terhadap kadar sulfat bakto agar yang dihasilkan.

Dari Gambar 5 diketahui bahwa peningkatan konsentrasi $\mathrm{NaOH}$ dan waktu pra perlakuan alkali membuat kadar sulfat bakto agar menjadi lebih kecil. Hal ini disebabkan karena penambahan alkali dalam proses pembuatan bakto agar dapat menghilangkan atau mengurangi kadar ester sulfat pada $\mathrm{C} 6$ dari rantai 1-4-L-galaktosa. Ester sulfat yang bereaksi dengan alkali membentuk garam-garam sulfat sehingga lebih mudah dipisahkan pada saat proses penyaringan. Menurut Amnidar (1989), tujuan utama proses perlakuan dengan alkali adalah untuk menghilangkan ester sulfat pada C6 rantai L-galaktosa. Alkali akan bereaksi dengan ester sulfat tersebut dan membentuk garam sulfat.

Setelah proses pra perlakuan alkali terjadi beberapa perubahan yaitu peningkatan kadar 3,6 anhidrogalaktosa dan penurunan kadar sulfat dari agar

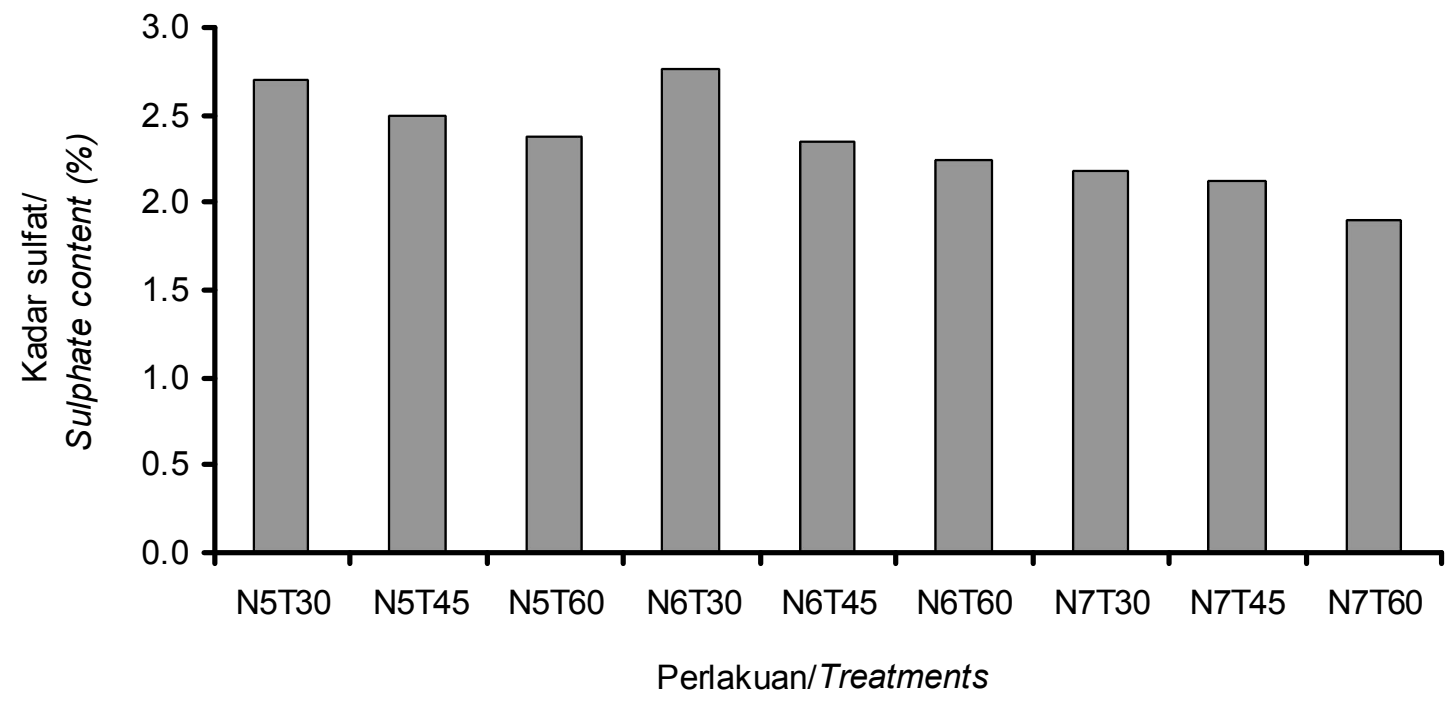

Keterangan/Note : $\quad \begin{aligned} \mathrm{N} 5 & =\mathrm{NaOH} 5 \% \\ \mathrm{~N} 6 & =\mathrm{NaOH} 6 \% \\ \mathrm{~N} 7 & =\mathrm{NaOH} 7 \% \\ \mathrm{~T} 30 & =\text { pra perlakuan alkali } 30 \text { menit/30 minutes alkali pre-treatment } \\ \mathrm{T} 45 & =\text { pra perlakuan alkali } 45 \text { menit/45 minutes alkali pre-treatment } \\ \mathrm{T} 60 & =\text { pra perlakuan alkali } 60 \text { menit/60 minutes alkali pre-treatment }\end{aligned}$

Gambar 5. Pengaruh konsentrasi $\mathrm{NaOH}$ dan waktu pra perlakuan alkali terhadap kadar sulfat bakto agar.

Figure 5. Effect of $\mathrm{NaOH}$ concentration and alkali pre-treatment on the sulphate content of bacto agar. 
(Anon., 2004a). Dari hasil penelitian lain dapat diketahui bahwa agar-agar yang dibuat dari rumput laut Gracilaria fatnfera tanpa proses pra perlakuan alkali memiliki kadar sulfat sebesar $2,5 \%$, sedangkan bila menggunakan proses pra perlakuan alkali terjadi penurunan kadar sulfat yaitu menjadi 1,1\% (Anon., 2004a). Ester sulfat pada C6 rantai galaktosa dapat dihilangkan dengan perlakuan alkali. Bersamaan dengan hilangnya ester sulfat akan terbentuk cincin 3,6 anhidro-galaktosa yang mempunyai rantai lurus, sehingga pembentukan gel akan mudah terjadi (Guiseley et al., 1980 dalam Amnidar, 1989).

Terdapat hubungan antara kadar sulfat yang dihasilkan dengan kekuatan gel dari bakto agar. Semakin tinggi kadar sulfat yang dihasilkan maka kekuatan gel yang dihasilkan akan semakin kecil. Hal ini karena ester sulfat pada atom karbon keenam dari L-galaktosa (C6) menyebabkan rantai polimer membentuk suatu tekukan yang dapat menghambat poses pembentukan gel (Glicksman, 1983). Hal ini sesuai dengan hasil penelitian yang didapatkan dimana kadar sulfat terendah dan kekuatan gel tertinggi diperoleh pada perlakuan N7T60 (konsentrasi $\mathrm{NaOH} 7 \%$ dan waktu pra perlakuan 60 menit).

\section{Kekuatan Gel}

Pada penelitian ini kekuatan gel bakto agar yang dihasilkan berkisar antara $534 \pm 0,04 \mathrm{~g} / \mathrm{cm}^{2}$ sampai dengan $748,5 \pm 9,19 \mathrm{~g} / \mathrm{cm}^{2}$. Secara umum nilai kekuatan gel bakto agar yang dihasilkan dari rumput laut Rhodymenia ciliata ini cukup tinggi. Nilai kekuatan gel agar yang dibuat dari rumput laut Gelidium memiliki kisaran kekuatan gel antara $300-500 \mathrm{~g} / \mathrm{cm}^{2}$ sedangkan kekuatan gel agar dari rumput laut Gracilaria sp. berkisar antara $50-300 \mathrm{~g} / \mathrm{cm}^{2}$ (Anon., 2004a). Kekuatan gel bakto agar yang dihasilkan dapat dilihat pada Gambar 6 .

Perlakuan variasi konsentrasi $\mathrm{NaOH}$, variasi waktu pra perlakuan alkali dan interaksi antara kedua perlakuan memberikan pengaruh yang nyata terhadap kekuatan gel bakto agar yang dihasilkan. Uji lanjut BNJ terhadap perlakuan variasi konsentrasi $\mathrm{NaOH}$ menunjukkan bahwa semua variasi konsentrasi yang

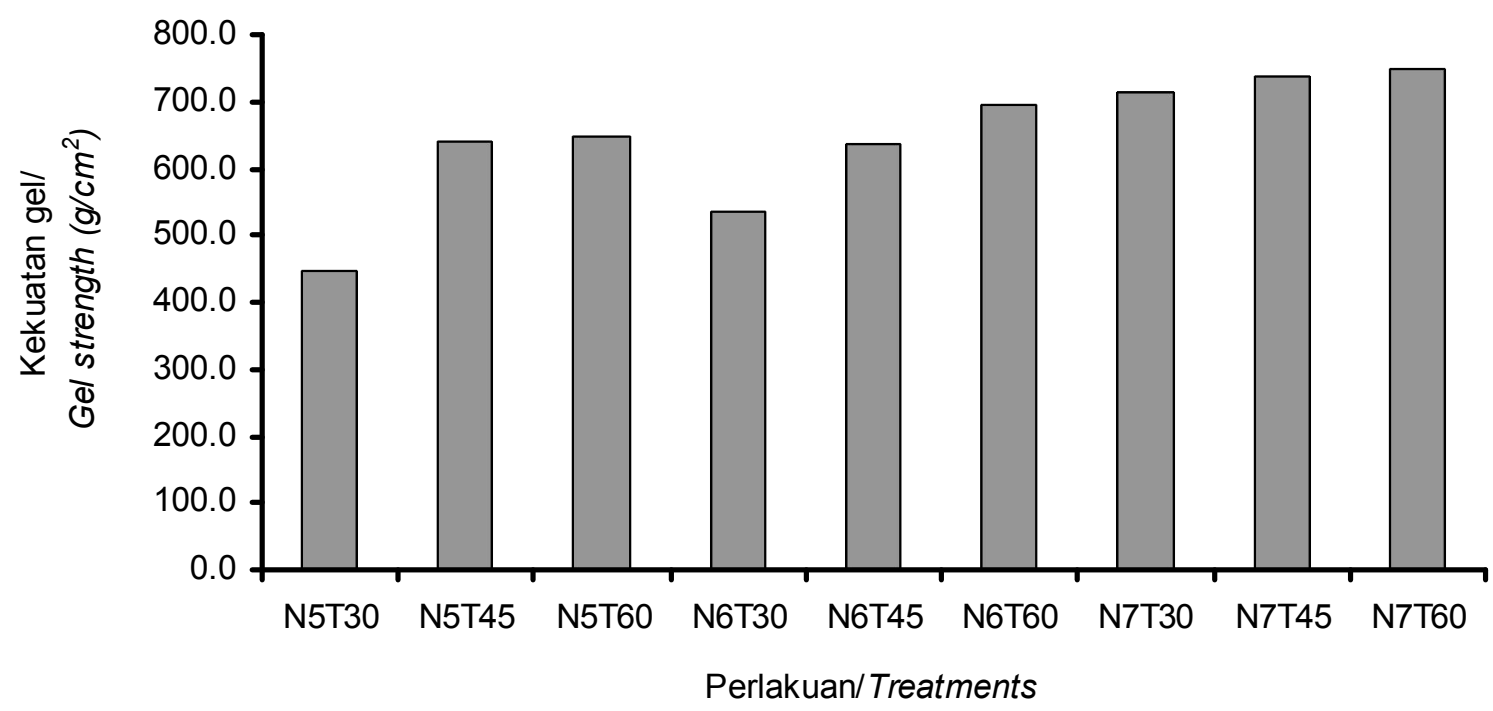

$\begin{array}{ll}\text { Keterangan/Note : } \quad & \mathrm{N} 5=\mathrm{NaOH} 5 \% \\ & \mathrm{~N} 6=\mathrm{NaOH} 6 \% \\ \mathrm{~N} 7=\mathrm{NaOH} 7 \% & \mathrm{~T} 30=\text { pra perlakuan alkali } 30 \text { menit/30 minutes alkali pre-treatment } \\ \mathrm{T} 45=\text { pra perlakuan alkali } 45 \text { menit } / 45 \text { minutes alkali pre-treatment } \\ \mathrm{T} 60=\text { pra perlakuan alkali } 60 \text { menit } / 60 \text { minutes alkali pre-treatment }\end{array}$

Gambar 6. Pengaruh konsentrasi $\mathrm{NaOH}$ dan waktu pra perlakuan alkali terhadap kekuatan gel bakto agar.

Figure 6. The effect of $\mathrm{NaOH}$ concentration and alkali pre-treatment on the gel strength of bacto agar. 
diberikan memberikan pengaruh yang nyata terhadap kekuatan gel bakto agar. Demikian pula hasil uji lanjut BNJ terhadap perlakuan variasi waktu pra perlakuan alkali diketahui bahwa semua variasi waktu yang diberikan memberikan pengaruh yang nyata terhadap kekuatan gel bakto agar.

Kekuatan gel suatu agar-agar dipengaruhi oleh jenis rumput laut, lokasi tempat tumbuhnya dan proses produksi dari agar-agar itu sendiri (Anon., 2004a). Hasil penelitian menunjukkan bahwa kekuatan gel bakto agar meningkat seiring dengan peningkatan konsentrasi $\mathrm{NaOH}$ dan waktu pra perlakuan alkali. Hal ini karena perlakuan pra perlakuan alkali dengan waktu yang cukup lama mampu mengurangi kadar sulfat dari bakto agar sehingga menghasilkan kekuatan gel yang lebih tinggi. Dari hasil penelitian ini diketahui bahwa kadar sulfat berbanding terbalik dengan kekuatan gel yang dihasilkan.

Menurut Rees (1969), kehadiran ester sulfat dalam rantai L-galaktosa bertindak sebagai "kink" yang dapat menghambat pembentukan pilinan ganda (double helix) pada proses pembentukan gel. Kekuatan gel dari agar dapat ditingkatkan dengan cara menambah jumlah 3,6 anhidro-galaktosa dan menghilangkan ester sulfat pada C6 dari L-galaktosa sehingga proses pembentukan pilinan ganda (double helix) tidak terhambat. Agar-agar yang memiliki kadar 3,6 anhidrogalaktosa yang lebih tinggi dan kadar sulfat yang rendah selalu menghasilkan kekuatan gel yang lebih tinggi (Anon., 2004a).

Jika dibandingkan dengan spesifikasi bakto agar komersial, maka bakto agar yang dihasilkan telah memenuhi persyaratan untuk ketiga grade (tingkat) yang ada. Untuk perlakuan penambahan $\mathrm{NaOH}$ sebanyak 5 dan $6 \%$ untuk semua variasi waktu pra perlakuan (30, 45 dan 60 menit) telah memenuhi persyaratan untuk standard grade sedangkan untuk penambahan $\mathrm{NaOH} 7 \%$ untuk semua variasi waktu pra perlakuan (30, 45 dan 60 menit) telah memenuhi persyaratan bakto agar yang lebih tinggi lagi yaitu premium grade.

\section{KESIMPULAN}

1. Hasil penelitian menunjukkan bahwa penambahan konsentrasi $\mathrm{NaOH}$ dan waktu pra perlakuan alkali memberikan pengaruh nyata terhadap peningkatan kadar sulfat dan kekuatan gel bakto agar, tetapi menurunkan rendemen secara nyata.

2. Variasi konsentrasi $\mathrm{NaOH}$ dan waktu pra perlakuan alkali tidak memberikan pengaruh nyata terhadap kadar air dan abu bakto agar yang dihasilkan.
3. Peningkatan konsentrasi $\mathrm{NaOH}$ hingga $7 \%$ dan waktu pra perlakuan alkali hingga 60 menit mampu menghasilkan bakto agar dengan kekuatan gel tertinggi dan kadar sulfat yang rendah walaupun rendemen yang dihasilkan lebih rendah dan kadar abu yang lebih tinggi.

4. Perlakuan terbaik diperoleh dari perlakuan N7T60 (konsentrasi $\mathrm{NaOH} \mathrm{7 \%} \mathrm{dan} \mathrm{waktu} \mathrm{pra}$ perlakuan 60 menit) dengan karakteristik mutu yaitu kekuatan gel $748,5 \pm 9,19 \mathrm{~g} / \mathrm{cm}^{2}$, kadar sulfat 1,90 $\pm 0,06 \%$, kadar air 13,12 $\pm 0,28 \%$, kadar abu 4,99 $\pm 0,06 \%$ dan rendemen 14,32 \pm $2,81 \%$.

\section{DAFTAR PUSTAKA}

Abdullah, A. 2004. Pengaruh Penambahan Khitosan terhadap Mutu Agar Bakto (Bacto Agar). Skripsi. Fakultas Perikanan dan IImu Kelautan IPB. Bogor. $75 \mathrm{pp}$.

Amnidar. 1989. Mempelajari Pengaruh Konsentrasi $\mathrm{NaOH}$ dan Waktu pada Perlakuan Alkali terhadap Mutu Agar-Agar dari Rumput Laut Gracilaria verrucosa. Skripsi. Fakultas Teknologi Pertanian IPB. Bogor. 70 pp.

Anonim. 1991. Prosiding Temu Karya Ilmiah Teknologi Pasca Panen Rumput Laut, 11-12 Maret. Buku II. Pusat Penelitian dan Pengembangan Perikanan. Jakarta. 172 pp.

Anonymous. 2004a. Properties, manufacture and application of seaweed polysaccharides - agar, carra-

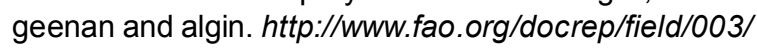
AB730E/AB730E00.htm. Diakses pada 11 Mei 2004.

Anonymous. 2004b. Supreme marine chemicals. http:// geocities.com/agar-agar/Supreme.html.

AOAC. 1984. Official Methods of Analysis of the Association of Official Analytical Chemists. 14 ed th A.O.A.C., Inc., Arlington, Virginia.

Chasanah, D.S.N. 2004. Kualitas Agarosa Hasil Isolasi dari Rhodymenia ciliata Menggunakan DAEASelulosa. Skripsi. Fakultas Perikanan dan IImu Kelautan IPB. Bogor. 42 pp.

Glicksman, M. 1983. Food Hydrocolloids. Vol. II. CRC Press. Inc. Boca Raton, Florida. 199 pp.

Rasyid, A., Rachmat, R., dan Murniasih T. 1998. Karakterisasi polisakarida agar dari Gracilaria $s p$. dan Gelidium sp. Makalah disajikan dalam Forum Komunikasi I. Ikatan Fikologi Indonesia (IFI). Serpong, 8 September 1999. p. 57-62.

Rees, D.A. 1969. Agar. Advances in Carbohydrate Chemistry and Biochemistry. 24: 267-332.

Steel, R.G.D. and Torrie, J.H. 1993. Prinsip dan Prosedur Statistika, Suatu Pendekatan Biometrik. Alih Bahasa B. Soemantri. PT. Gramedia Pustaka Utama. Jakarta. p. 377-398.

Subaryono, Utomo, B.S.B., Wikanta, T. dan Satriyana, N. 2003. Pengaruh penambahan iota karaginan pada ekstraksi agarosa dari agar-agar menggunakan cetyl 
piridinium klorida. J. Penel. Perik. Indonesia. 9(5): 1-9.

Utomo, B.S.B, Zilda, D.S., Heruwati, E.S., Lestari, D.S., Subaryono, Murdinah dan Suryanti. 2003. Pengembangan produk fikokoloid sebagai subtitusi untuk gelatin. Laporan Teknis Pusat Riset Pengolahan Produk dan Sosial Ekonomi Kelautan dan Perikanan. Jakarta. 42 pp.

Winarno, F.G. 1990. Teknologi Pengolahan Rumput Laut. Pustaka Sinar Harapan, Jakarta. 112 pp. 